\title{
Teaching NeuroImages: An imaging clue for treatable early childhood-onset dystonia: Manganism
}

Hansashree Padmanabha, MD, DM, Savita Krishnamurthy, MD, GG Sharath Kumar, MD, DM, Indumathi Chikkanayakana, MD, Aruna Sethuraman, MD, and Thomas Mathew, MD, DM

Neurology ${ }^{\circledR}$ 2019;92:e628-e629. doi:10.1212/WNL.0000000000006881
Correspondence

Dr. Padmanabha

hansa777@gmail.com

Figure Axial T1-weighted image, sagittal T1-weighted image, and T2* gradient-recalled echo (GRE) axial image

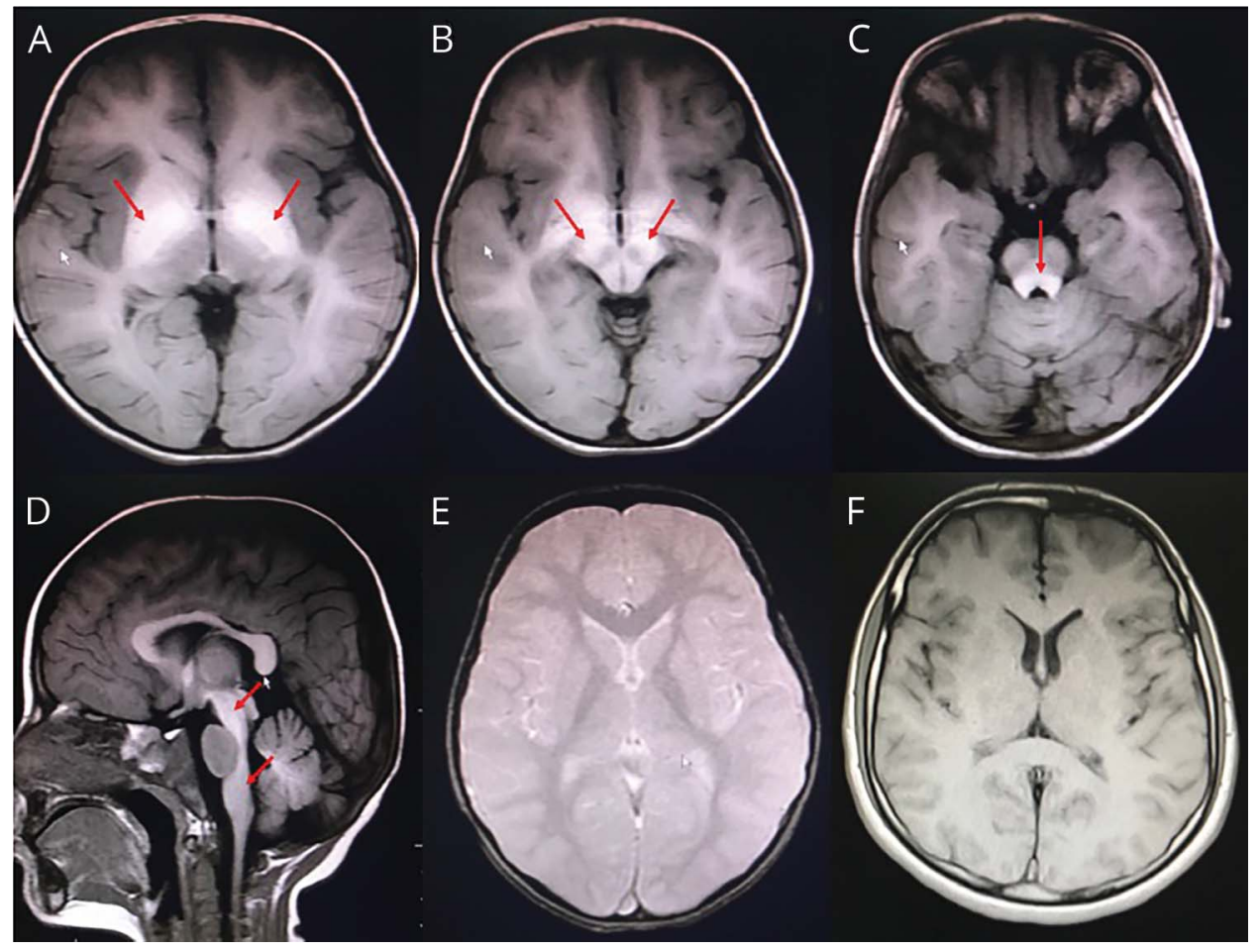

Axial T1-weighted image shows bright signal intensity (T1 shortening) in the (A) Globus pallidus, (B) Substantia nigra, and (C) Tectum of pons. (D) Sagittal T1-weighted image shows bright signal intensity in the dorsal brainstem. (E) T2* GRE axial image at the level of basal ganglia shows no evidence of blooming (unlike iron or calcium deposition, manganese deposition will not cause blooming on T2* GRE or susceptibility-weighted imaging). (F) Normal axial T1-weighted image for comparison at the level of basal ganglia shows no signal changes.
A 3-year-old boy, born of consanguineous parentage, presented with recurrent falls and toe-walking from 2 years. Examination showed microcephaly ( $45 \mathrm{~cm}$; $<-3 \mathrm{Z}$ score, WHO), dysarthria, and bilateral foot dystonia. Neuroimaging revealed multiple areas of T1-weighted hyperintensities, including in the basal ganglia and dorsal brainstem (figure). Serum manganese was elevated at $186 \mathrm{mg} / \mathrm{L}$ (normal 5-15 mg/L) with hemoglobin of $14.5 \mathrm{~g} / \mathrm{dL}$ (normal 11.5-15.5 g/dL). Next-generation sequencing revealed novel homozygous single base pair insertion c.18_19insT (p.Lys7Ter) in exon 1 of the SLC30A10 gene.

The SLC30A10 gene is a cell surface localized manganese efflux transporter and loss of function mutations lead to accumulation of manganese in liver and brain. ${ }^{1}$ It is inherited autosomal recessively and manifests in childhood (2-15 years) with 4-limb dystonia, dysarthria, polycythemia,

\section{MORE ONLINE}

\section{$\rightarrow$ Teaching slides}

links.lww.com/WNL/

A801

From the Department of Neurology (H.P.), National Institute of Mental Health and Neurosciences, Bangalore; and the Departments of Pediatrics (S. Krishnamurthy, I.C., A.S.) and Neurology (S. Kumar GG, T.M.), St John's Medical College, Karnataka, India.

Go to Neurology.org/N for full disclosures. Funding information and disclosures deemed relevant by the authors, if any, are provided at the end of the article. 
hepatic cirrhosis, and characteristic neuroimaging. ${ }^{2}$ EDTA chelation and iron supplementation might be beneficial. ${ }^{2}$

\section{Author contributions}

Hansashree Padmanabha: study concept and design, first draft, literature review, critical review of manuscript for intellectual content. Savita Krishnamurthy: study concept and design, first draft, literature review. Sharath Kumar GG: study concept and design, neuroimaging discussion. Indumathi Chikkanayakana: study concept and design, first draft, literature review. Aruna Sethuraman: study concept and design, first draft, literature review. Thomas Mathew: study concept and design, first draft, literature review.

\section{Study funding}

No targeted funding reported.

\section{Disclosure}

The authors report no disclosures relevant to the manuscript. Go to Neurology.org/N for full disclosures.

\section{References}

1. Tuschl K, Clayton PT, Gospe SM Jr, Mills PB. Dystonia/parkinsonism, hypermanganesemia, polycythemia, and chronic liver disease. In: Adam MP, Ardinger $\mathrm{HH}$ Pagon RA, et al, editors. GeneReviews [Internet]. Seattle: University of Washington; 2012:1993-2018.

2. Stamelou M, Tuschl K, Chong WK, et al. Dystonia with brain manganese accumulation resulting from SLC30A10 mutations: a new treatable disorder. Mov Disord 2012;27:1317-1322. 


\section{Neurology}

\section{Teaching NeuroImages: An imaging clue for treatable early childhood-onset dystonia: Manganism}

Hansashree Padmanabha, Savita Krishnamurthy, GG Sharath Kumar, et al.

Neurology 2019;92;e628-e629

DOI 10.1212/WNL.0000000000006881

This information is current as of February 4, 2019

\section{Updated Information \&} Services

References

Permissions \& Licensing

Reprints including high resolution figures, can be found at: http://n.neurology.org/content/92/6/e628.full

This article cites 1 articles, 0 of which you can access for free at: http://n.neurology.org/content/92/6/e628.full\#ref-list-1

Information about reproducing this article in parts (figures,tables) or in its entirety can be found online at:

http://www.neurology.org/about/about_the_journal\#permissions

Information about ordering reprints can be found online:

http://n.neurology.org/subscribers/advertise

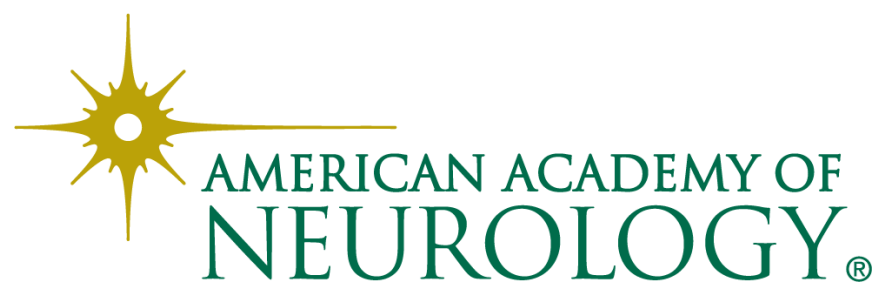

